\title{
Enhanced type III collagen gene expression during bleomycin induced lung fibrosis
}

\author{
S Shahzeidi, B Mulier, B de Crombrugghe, P K Jeffery, R J McAnulty, G J Laurent
}

\begin{abstract}
Background-Intratracheal instillation of bleomycin into mice leads to deposition of collagen in the lung and fibrosis, but the mechanism for this is poorly understood. Enhanced collagen gene expression, increased collagen synthesis, decreased collagen degradation, and proliferation of fibroblasts have all been proposed as possible contributors. To obtain information on the activity of collagen producing cells at an early stage in the development of pulmonary fibrosis in situ hybridisation was used to detect and localise products of the type III procollagen gene. In addition, assay of type III procollagen gene expression was performed using dot-blot analysis of lung RNA extracts.
\end{abstract}

Methods-Lung fibrosis was induced in mice by intratracheal instillation of bleomycin sulphate $(6 \mathrm{mg} / \mathrm{kg}$ body weight) and tissues were examined after three, 10,21 and 35 days. RNA-RNA hybridisation was accomplished with riboprobes labelled with sulphur-35 which were generated from a $1.7 \mathrm{~kb}$ mouse procollagen $a_{1}$ (II) cDNA. In situ hybridisation was performed on sections fixed in paraformaldehyde and embedded in paraffin wax and steady state values of type III procollagen mRNA were assayed by dot-blot analysis of total lung RNA extracted by guanidium isothiocyanate.

Results-Data obtained using both techniques suggest that type III procollagen gene expression was enhanced in bleomycin induced fibrosis and that expression was maximal between 10 and 35 days after a single dose of bleomycin. The most active cells were located in interstitial areas around the conducting airways, although these cells were usually seen in areas with no histological evidence of fibrosis. Regions with the most advanced fibrosis, as assessed by histological methods, rarely contained cells with activity above the threshold detectable by this technique.

Conclusions-These results suggest that activation of interstitial fibroblasts, with enhanced type III collagen gene expression, forms at least part of the mechanism leading to increased collagen deposition in bleomycin induced fibrosis and that this occurs before fibrosis is detected by conventional histological staining.

(Thorax 1993;48:622-628)

To maintain its primary function in gas exchange the lung depends on a network of diverse structural elements which determines its elastic properties, and also plays a part in regulating cell-cell contact and determining cell function. ${ }^{1}$ Among these matrix elements the most abundant components are the collagens, with types I and III collagens the most widely distributed in both airways and parenchymal structures. The ordered distribution of these proteins is vital to maintain the structural properties of lung tissue while allowing gas exchange to proceed freely within alveoli. This property is compromised in several respiratory disorders, whose most common feature is pulmonary fibrosis. Fibrosis may be associated with known agents-for example, asbestos or drugs such as bleomycin-but sometimes the causes are unknown such as in cryptogenic fibrosing alveolitis (idiopathic pulmonary fibrosis) or in association with diseases such as systemic sclerosis or sarcoidosis. All these disorders are characterised by inflammation, thickening of the alveolar wall, and excessive deposition of predominantly type I and III collagens. ${ }^{2-5}$

To examine the pathogenesis of pulmonary fibrosis different experimental models in animals have been developed, the most common of which entails the intratracheal instillation of bleomycin. ${ }^{6}$ The histological pattern of fibrosis in bleomycin induced fibrosis is similar to that seen in humans, although the time course for development is much shorter. For example, in mice the increase in collagen content is maximal about two months after a single dose of bleomycin given intratracheally. ${ }^{7}$

Increased rates of collagen synthesis in the lung have been reported in bleomycin induced fibrosis by several groups using in vitro and in vivo techniques. ${ }^{89}$ Degradation has been less well studied, but reduced degradation may also contribute to the increased lung collagen content. ${ }^{8}$ To investigate further the mechanisms leading to enhanced collagen production several studies have examined the activity of procollagen genes during the

Received 24 August 1992 Returned to authors Revised version received 18 January 1993 
development of pulmonary fibrosis and reported increased amounts of messenger RNA (mRNA) coding for procollagens I and III. ${ }^{10-12}$ This may suggest enhanced expression of procollagen genes in lung parenchymal cells, but other interpretations are possible. For example, the numbers of fibroblasts in the lung increase after bleomycin treatment, which may be reflected by changes in mRNA rather than altered expression of existing cells. Furthermore, all these studies were based on analyses of an aliquot of total RNA that had been immobilised on a solid membrane. Such analyses provide no information on sites of gene activation in the lungs of animals developing fibrotic lesions. In this study we used Northern blot analysis and in situ hybridisation to measure and localise type III procollagen gene expression during the development of bleomycin induced fibrosis in mice.

\section{Methods}

\section{ANIMALS}

Mice (strain $B_{6} D_{2} F_{1}$ ) aged eight to nine weeks and weighing 24-26 g were anaesthetised using Alphaxolon $0.9 \% \mathrm{w} / \mathrm{v}$ and Alphadolon $0.3 \% \mathrm{w} / \mathrm{v}$ (Glaxo), given intraperitoneally at a dose of $75 \mathrm{ml} / \mathrm{kg}$ body weight. Bleomycin (Lundbeck) was then administered in $0.05 \mathrm{ml}$ of $0.14 \mathrm{M}$ sodium chloride at a dose of 6 $\mathrm{mg} / \mathrm{kg}$ body weight. Control groups received $0.05 \mathrm{ml}$ of $0.14 \mathrm{M}$ sodium chloride alone. Three, 10, 21, and 35 days later animals were killed by an overdose of pentobarbitone as described previously. ${ }^{7}$ Biochemical analyses were performed on at least four animals in each group, but in most cases six animals were used. For different experiments the precise numbers of animals are given in the figure and table legends. In situ hybridisation was performed on at least two different animals at each time point.

Lungs were fixed by intratracheal instillation of $4 \%$ paraformaldehyde in phosphate buffered saline at a pressure of $25 \mathrm{~cm} \mathrm{H}_{2} \mathrm{O}$. The trachea was ligated just caudal to the larynx and the contents of the thorax removed as one unit. Tissues were treated with $15 \%$ sucrose in phosphate buffered saline before being dehydrated and embedded in paraffin wax.

For measurement of collagen content animals were killed and lungs perfused with $2 \mathrm{ml}$ of phosphate buffered saline at $4^{\circ} \mathrm{C}$. Total lung collagen content was assessed by measuring hydroxyproline, which was determined spectrophotometrically after oxidation with chloramine- $T$ and extraction of the toluene miscible product. ${ }^{13}$

\section{TISSUE PREPARATION}

In situ hybridisation was accomplished based on techniques described previously. ${ }^{14} 15$ These methods and the modifications adopted are described briefly.

Sections ( $5 \mu \mathrm{m}$ thick) were cut and placed on slides previously coated with a $2 \% \mathrm{v} / \mathrm{v}$ solution of 3-aminopropyltriethoxysilane in acetone. After dewaxing, sections were rehydrated through a series of alcohol washes of decreasing concentration, followed by immersion in $0.14 \mathrm{M}$ sodium chloride and phosphate buffered saline before refixing with 4\% paraformaldehyde. To allow optimum entry of the probe into cells sections were digested with proteinase- $\mathrm{K}(20 \mu \mathrm{g} / \mathrm{ml}$ in $50 \mathrm{mM}$ TRIS hydrochloride), $5 \mathrm{mM}$ EDTA (pH 7.5 buffer) for 7.5 minutes before fixing with paraformaldehyde. To decrease surface charges slides were immersed in $0.1 \mathrm{M}$ triethanolamine followed by dehydration through a series of increasing concentrations of ethanol.

PREPARATION OF THE PROBE

To perform hybridisation experiments we used a $1 \cdot 7 \mathrm{~kb}$ cDNA Eco $R_{1}$ fragment containing the second exon of the mouse type III $\left(a_{1}\right)$ procollagen gene. ${ }^{16}$ This construct was initially cloned in pBR322 and, after large scale preparation, using polyethylene glycol precipitation, ${ }^{14}$ the plasmid was digested with $\mathrm{EcoR}_{1}$ and ligated into pAM18. To generate antisense and sense riboprobes in vitro transcription was performed using T7 or SP6 RNA polymerases respectively in the presence of uridine triphosphate labelled with sulphur-35 (Amersham International). Solutions were then treated with RNAse free DNAse (Boehringer, Germany) with yeast transfer RNA added as a carrier and dithiothreitol added to minimise oxidation of the probe. Probes were then alkaline hydrolysed for 60 minutes in a buffer containing $80 \mathrm{mM}$ sodium carbonate and $120 \mathrm{mM}$ sodium bicarbonate and then neutralised in a $200 \mathrm{mM}$ acetate buffer. This hydrolysis is performed to generate polynucleotides of about 50 base pairs long. This has been shown previously to be an appropriate length for the probe to enter the cells and hybridise optimally with mRNA species. Labelled probes then were separated from unincorporated nucleotides by loading on to a column of sterile Sephadex G-50 preblocked with yeast RNA and eluted with 10 $\mathrm{mM}$ TRIS hydrochloride $(\mathrm{pH} 7 \cdot 5)$ containing $5 \mathrm{mM}$ EDTA and $0 \cdot 1 \%$ sodium lauryl sulphate. Fractions containing radioactivity were combined and the probe precipitated with $0 \cdot 1$ volumes of $3 \mathrm{M}$ sodium acetate and 2.5 volumes of ethanol at $-70^{\circ} \mathrm{C}$ for 15 minutes. After centrifugation the pellet was resuspended in $10 \mathrm{mM}$ dithiothreitol to achieve a concentration of $5 \times 10^{5}$ counts per minute per $\mu l$ of the probe.

\section{IN SITU HYBRIDISATION}

The hybridisation solution comprised one part probe to nine parts hybridisation buffer ( $50 \%$ formamide, $300 \mathrm{mM}$ sodium chloride,

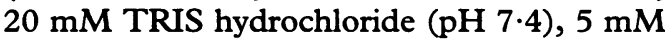
EDTA, $10 \mathrm{mM}$ sodium monophosphate $\mathrm{pH}$ $8.0), 10 \%$ dextran sulphate, normal strength Denhardt's solution of a mixture of $50 \%$ formamide with dextran sulphate) and 500 $\mu \mathrm{g} / \mathrm{ml}$ yeast RNA ( $25 \mu \mathrm{l})$ was applied to each tissue section and covered with siliconised coverslips. Sections were incubated for 16 
hours at $42^{\circ} \mathrm{C}$ in a chamber humidified with a solution of $50 \%$ formamide in twice standard sodium citrate solution. The optimal incubation temperature $\left(42^{\circ} \mathrm{C}\right)$ was determined from the melting point of the probe $\left(T_{m}\right)$ based on the salt concentration in the hybridisation solution and the base composition of the probe.

\section{WASHINGS AFTER HYBRIDISATION}

After hybridisation, slides were washed in twice standard sodium citrate solution, 10 $\mathrm{mM}$ dithiothreitol at $50^{\circ} \mathrm{C}$ for 30 minutes, $50 \%$ formamide, twice standard sodium citrate solution, $10 \mathrm{mM}$ dithiothreitol at $65^{\circ} \mathrm{C}$ for 20 minutes, and in twice standard sodium citrate solution at $37^{\circ} \mathrm{C}$ for two washes of 10 minutes each. Sections were then treated at $37^{\circ} \mathrm{C}$ for 30 minutes with a solution of four times standard sodium citrate solution containing $20 \mu \mathrm{g} / \mathrm{ml}$ RNase-A followed by washes of twice standard sodium citrate solution at $37^{\circ} \mathrm{C}$ for 10 minutes and a tenth of standard sodium citrate solution at $37^{\circ} \mathrm{C}$ for 15 minutes. Finally sections were dehydrated in a series of washes with alcohol containing $0.3 \mathrm{M}$ ammonium acetate and air dried.

\section{AUTORADIOGRAPHY}

Sections were dipped into a photographic emulsion $\left(K_{5}\right.$, Ilford) previously warmed to $42^{\circ} \mathrm{C}$ and diluted $(1: 1)$ with distilled water. Slides were allowed to dry in the dark for two hours and then placed in a light tight box with silica gel for two or three weeks at $4^{\circ} \mathrm{C}$. Slides were immersed in developer for 3.5 minutes (D19, Kodak) and then into fixer for two minutes (Rapid fixer, Ilford), followed by several quick rinses with distilled water. Sections were then counterstained with haematoxylin, dehydrated through a series of ethanol washes, and mounted in Cytoseal 60 media (BDH).

\section{RNA ISOLATION AND NORTHERN ANALYSIS}

Total lung RNA was isolated by the guanidium isothiocyanate and phenol chloroform technique as described by Maniatis et al..$^{15}$ For Northern analysis RNA was electrophoresed in an agarose gel containing $1 \%$ formaldehyde and transferred to a membrane (Hybond, Amersham International). For assay RNA samples were also spotted directly on to a Hybond membrane in a commercially available dot-blot apparatus (Gibco). Riboprobes labelled with uridine triphosphate radiolabelled with phosphorus32 were generated by in vitro transcription and hybridisation was carried out in $50 \%$ formamide (five times standard sodium citrate solution containing 10 times standard Denhardt's solution, $0 \cdot 1 \%$ sodium dodecyl sulphate (SDS), and $100 \mu \mathrm{g} / \mathrm{ml}$ denatured salmon sperm DNA) for 20 hours at $42^{\circ} \mathrm{C}$. After hybridisation filters were washed twice in twice standard sodium citrate solution and $0 \cdot 1 \%$ SDS at room temperature, followed by two washes in a fifth of standard sodium citrate solution and $0.1 \%$ SDS at $40^{\circ} \mathrm{C}$.

Hybridisation filters were exposed to $x$ ray films (Kodak) at $-80^{\circ} \mathrm{C}$ and autoradiographs developed in Fuji medical film processor (GFII) after three days of exposure. For quantification, autoradiographs of the dotblots were scanned using an Apple Macintosh based image analysis system with an Abaton scanner. Amounts of type III mRNA were measured per unit total RNA and as a ratio compared with the $\beta$-actin mRNA.

\section{Results}

Figure 1 shows the changes in lung collagen content in animals treated with bleomycin compared with controls killed at the same times. Collagen contents of bleomycin treated animals were not different from controls at three days, but by 10 days had increased by about $40 \%(p<0.05)$. After this time there was a further increase and by 35 days the content was almost twice that of controls $(\mathrm{p}<0.01)$.

Extensive fibrosis was apparent by light microscopy in animals 35 days after bleomycin administration (fig 2). In the lungs of these animals there were many areas in which the normal architecture, with fine alveolar septa, was lost while other areas were apparently normal.

Figure 3 shows the highly specific hybridisation of riboprobes coding for type III procollagen and $\beta$-actin with mRNA isolated from mouse lung. Probes hybridised to specific mRNA species with molecular weights of $5 \cdot 6$ kilobases and $2 \cdot 3$ kilobases, corresponding to the size of mRNAs for type III procollagen and $\beta$-actin probes respectively.

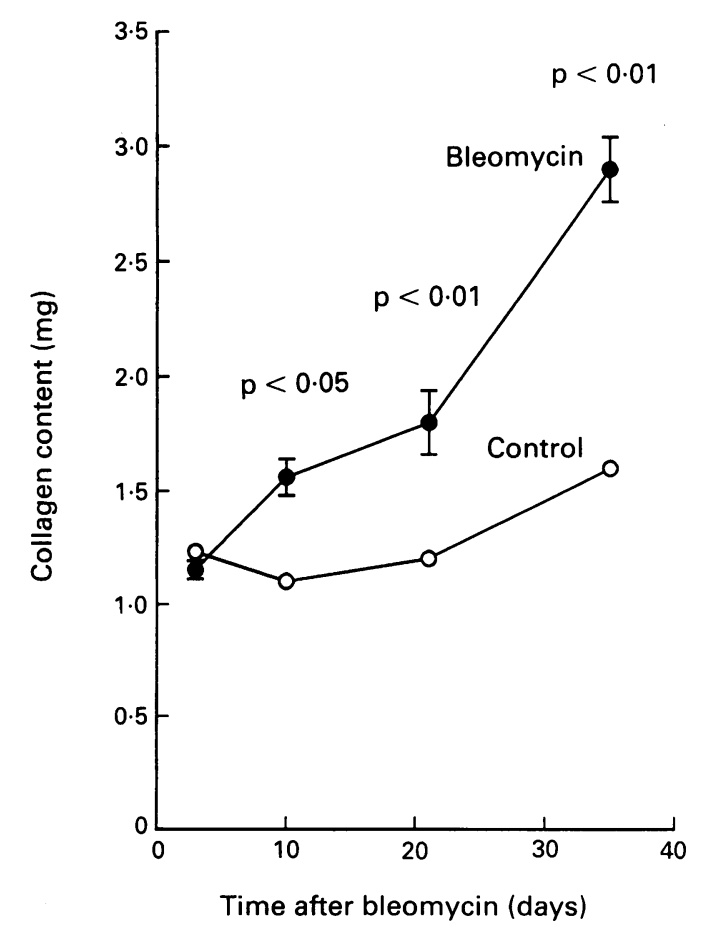

Figure 1 Time course for changes in lung collagen content during the development of bleomycin induced pulmonary fibrosis in mice. All values shown for treated (O) and control animals (O) are means (SE) for at least six animals. Where error bars are not shown they are confined within the area of the dots. 

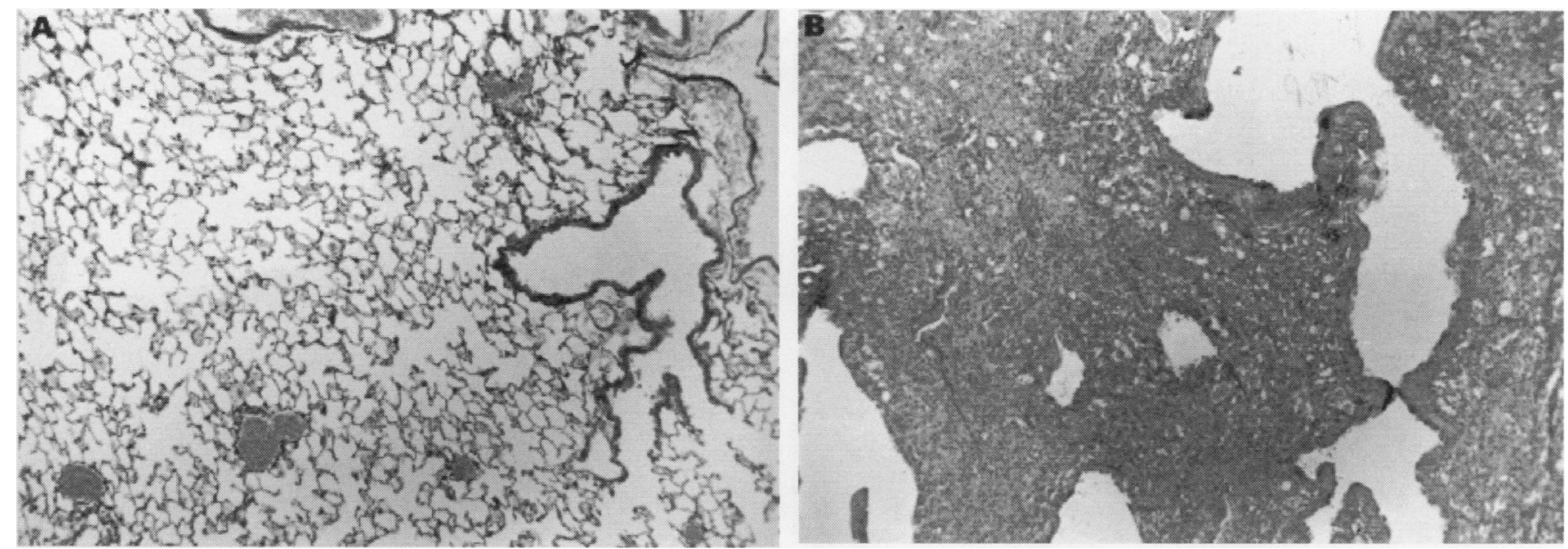

Figure 2 Lung of (A) normal mice and (B) of mice with pulmonary fibrosis 35 days after administration of saline or bleomycin respectively. (Haematoxylin and eosin).

The table shows the changes in total lung RNA content as well as type III procollagen and $\beta$-actin mRNAs in the lungs of control and treated mice. Ten days after administration of bleomycin the total RNA in the lung was not significantly different from that in control animals but by 35 days it had increased about threefold $(p<0.001)$. Type III procollagen mRNA, expressed per unit weight of total RNA, doubled by day 10 $(\mathrm{p}<0.01)$ but by day 35 had returned to control values. When type III procollagen was expressed as a total amount in the lung there was a significant increase at both times, with a more than threefold increase by 35 days $(\mathrm{p}<0.05)$. When expressed as a ratio to $\beta$ actin mRNA there was a significant increase at 35 days only $(p<0.05)$.

Figure 4 shows the localisation of type III procollagen mRNA in a section of lung from an animal 21 days after bleomycin treatment. Dark and light field views of the same section indicate type III procollagen gene activation within interstitial cells, particularly those located in peribronchiolar areas. In control animals hybridisation was apparent only in subpleural areas (fig $5 \mathrm{~A}$ and $\mathrm{B}$ ). In other than subpleural sections there was a diffuse distribution of signal, but this was not apparently different from that due to non-specific interaction of the probe with tissue (fig $5 \mathrm{C}$ and $\mathrm{D}$ ).
To ensure that the hybridisation signals shown in figs 4 and 5 were specific for type III procollagen mRNA, similar sections were exposed to the sense riboprobe. These probes gave no specific signals, although a uniform low grade diffuse background was observed throughout the slides in areas with and without tissue. However, even in cases in which the sense probe background was high (fig 6A) sequential sections from the same tissue hybridised with the antisense probe clearly showed enhanced expression in specific areas (fig 6B).

\section{Discussion}

The time course for development of pulmonary fibrosis in various experimental models in animals depends on the strain of the animal as well as the dose and route of introduction of the fibrotic agent. The dose of bleomycin used in this study was chosen because it induced rapid production and deposition of collagen without overt systemic toxicity. In previous studies of the same strain of mouse the earliest fibrotic lesions were reported at 21 days, with more extensive fibrosis at 35 and 60 days. ${ }^{7}$ Our results confirm that the extensive but patchy fibrosis was apparent after 35 days.

Changes in collagen synthesis and degrada-

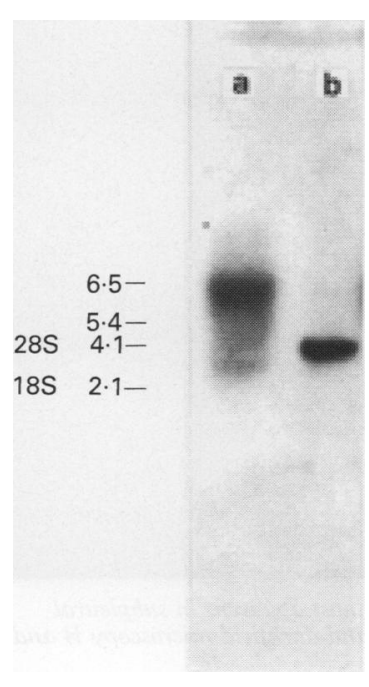

Figure 3 Northern analysis of $m R N A$ for type III procollagen (lane a) and $\beta$-actin (lane $b$ ). Riboprobes labelled with phosphorus- 32 were generated using $T_{\text {, }}$ polymerase and applied to Hybond membranes, on which $10 \mu \mathrm{g} R \mathrm{R} A$ was immobilised as described in the methods section. The positions for $18 S$ and $28 S$ ribosomal RNAs were determined by ethidium bromide staining of the gel before transfer to the membrane. Both these species ran in positions slightly lower than either the type III procollagen or $\beta$-actin $m R N A$ s and cross-hybridisation was not observed.
Mean (SE) changes in steady state $m R N A$ contents of type III procollagen in lungs of mice after bleomycin.

\begin{tabular}{|c|c|c|c|}
\hline \multirow[t]{2}{*}{$R N A$} & \multirow[t]{2}{*}{ Control $(n=9)$} & \multicolumn{2}{|c|}{ Bleomycin $(n=8)$} \\
\hline & & $\begin{array}{l}10 \text { days } \\
(n=4)\end{array}$ & $\begin{array}{l}35 \text { days } \\
(n=4)\end{array}$ \\
\hline Total RNA ( $\mu$ g RNA/lung) & $189 \cdot 2(27 \cdot 9)$ & $165.9(55.6)$ & $570 \cdot 2(37 \cdot 2) \ddagger$ \\
\hline $\begin{array}{l}\text { Type III procollagen: } \\
\text { mRNA } \mu \text { g RNA } \\
\text { total mRNA/lung }\end{array}$ & $\begin{array}{l}1.59(0.23) \\
264(43)\end{array}$ & $\begin{array}{l}3 \cdot 25(0 \cdot 44 \dagger \\
534(158)^{\star}\end{array}$ & $\begin{array}{l}1 \cdot 47(0 \cdot 45) \\
882(324)^{\star}\end{array}$ \\
\hline $\begin{array}{l}\text { Ratio of type III } \\
\quad \text { procollagen to } \beta \text {-actin }\end{array}$ & $0.33(0.05)$ & $0.29(0.04)$ & $0.61(0.13)^{\star}$ \\
\hline
\end{tabular}

${ }^{\star} \mathrm{p}<0.05, \mathrm{fp}<0.01, \neq \mathrm{p}<0.001$. 


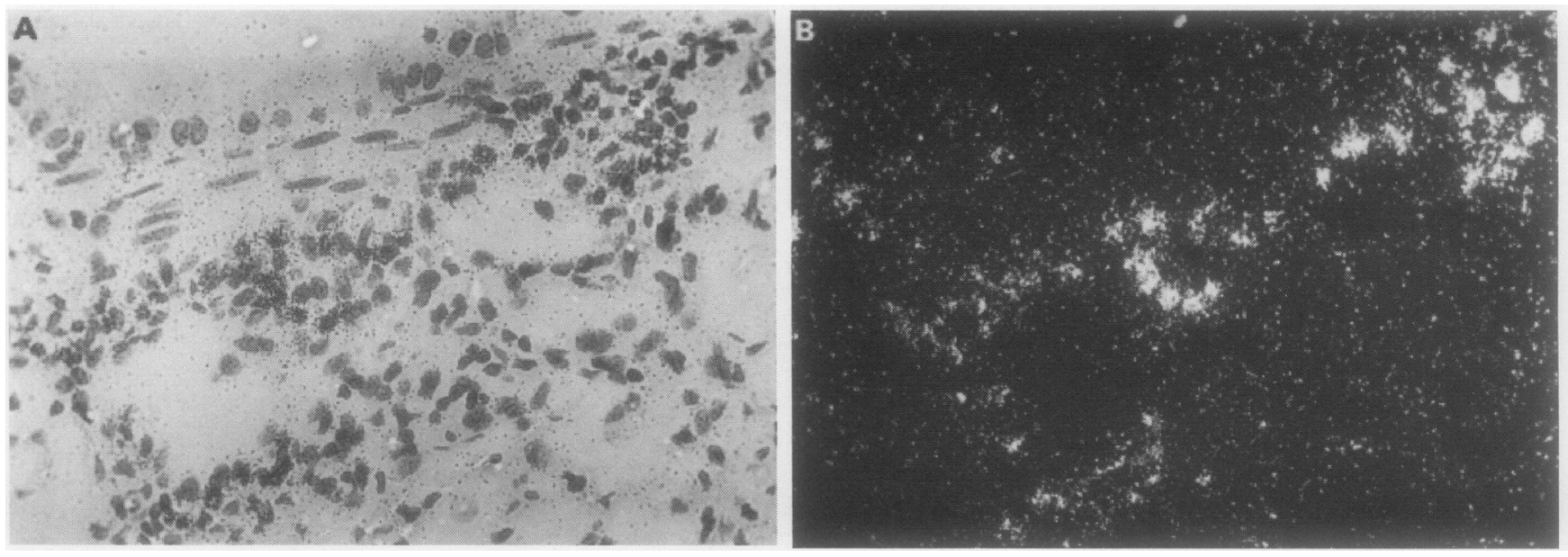

Figure 4 Localisation of type III procollagen mRNA in lung from an animal 21 days after bleomycin treatment. Lung sections were prepared as described in the methods section and treated with an antisense RNA probe labelled with sulphur-35. After three weeks slides were developed and examined by $(A)$ phase contrast or $(B)$ darkfield microscopy.

tion have previously been investigated in bleomycin induced pulmonary fibrosis. There is abundant evidence for enhanced collagen synthesis, based on uptake of radiolabelled proline into collagen, ${ }^{89}$ and in one of these studies a concomitant decrease in the rate of rapid collagen degradation was reported. ${ }^{8}$

Enhanced production of lung collagens could be mediated at several points during collagen gene expression and biosynthesis. ${ }^{1}$ One possibility might be regulation by changes in transcription rate or the stability of mRNA for procollagens. Concentrations of
mRNA for procollagens I and III are increased during bleomycin induced fibrosis. ${ }^{10-12}$ However, in all these studies mRNA was extracted from the lung and therefore the results cannot assess whether increases derive from changes in cell number or changes in procollagen mRNA production by existing cells, or both. There is evidence for fibroblast proliferation in bleomycin induced pulmonary fibrosis in hamsters ${ }^{17}$ so changes in cell number need to be assessed.

The introduction of in situ hybridisation techniques allows the question of whether
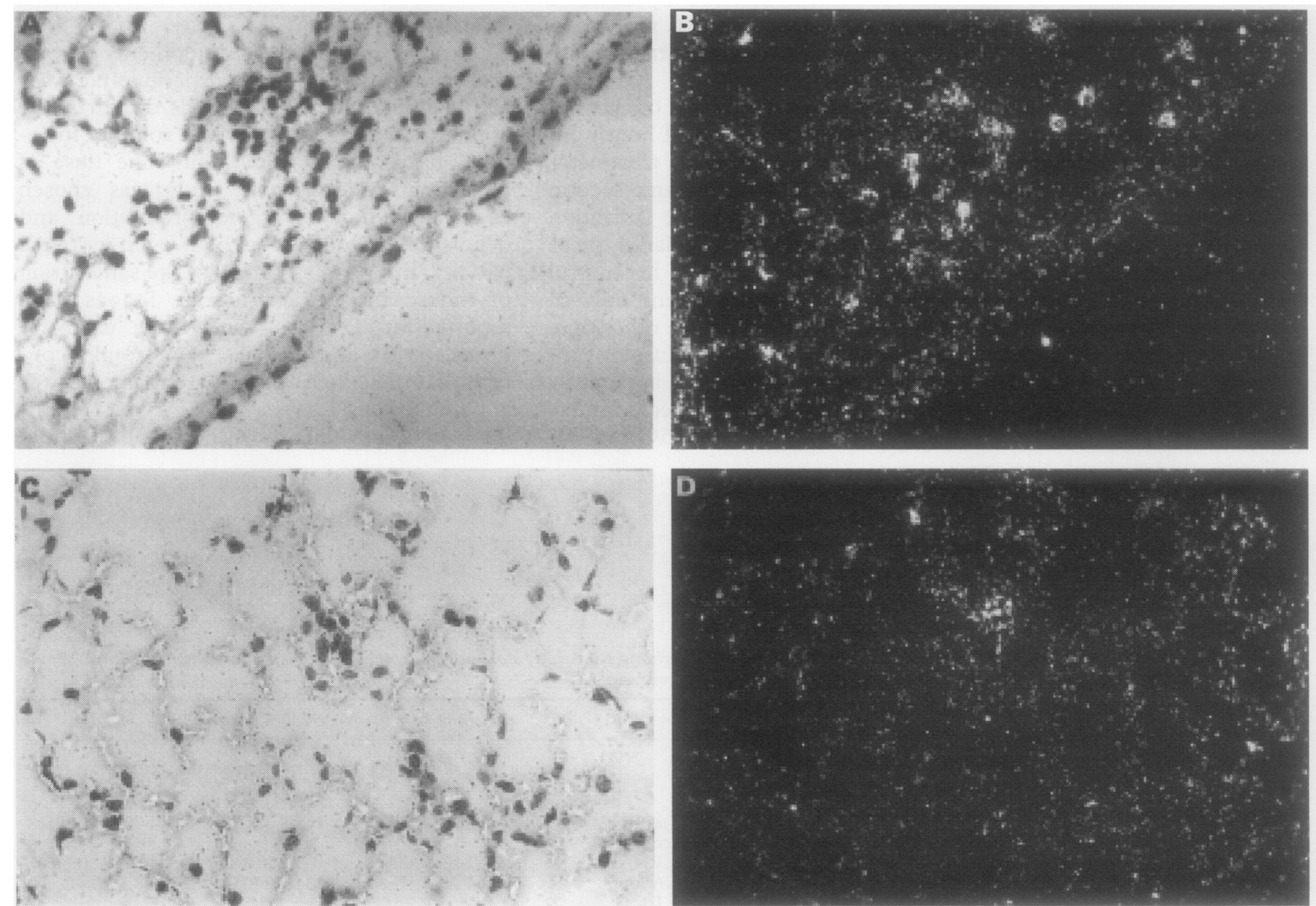

Figure 5 Localisation of type III procollagen $m R N A$ in lung from a normal animal. Hybridisation to antisense probe was most apparent in subpleural areas ( $A$ and $B$ ). Application of sense probe showed apparently non specific binding ( $C$ and $D$ ). (Phase contrast $A$ and $C$ and darkfield microscopy $B$ and D). 

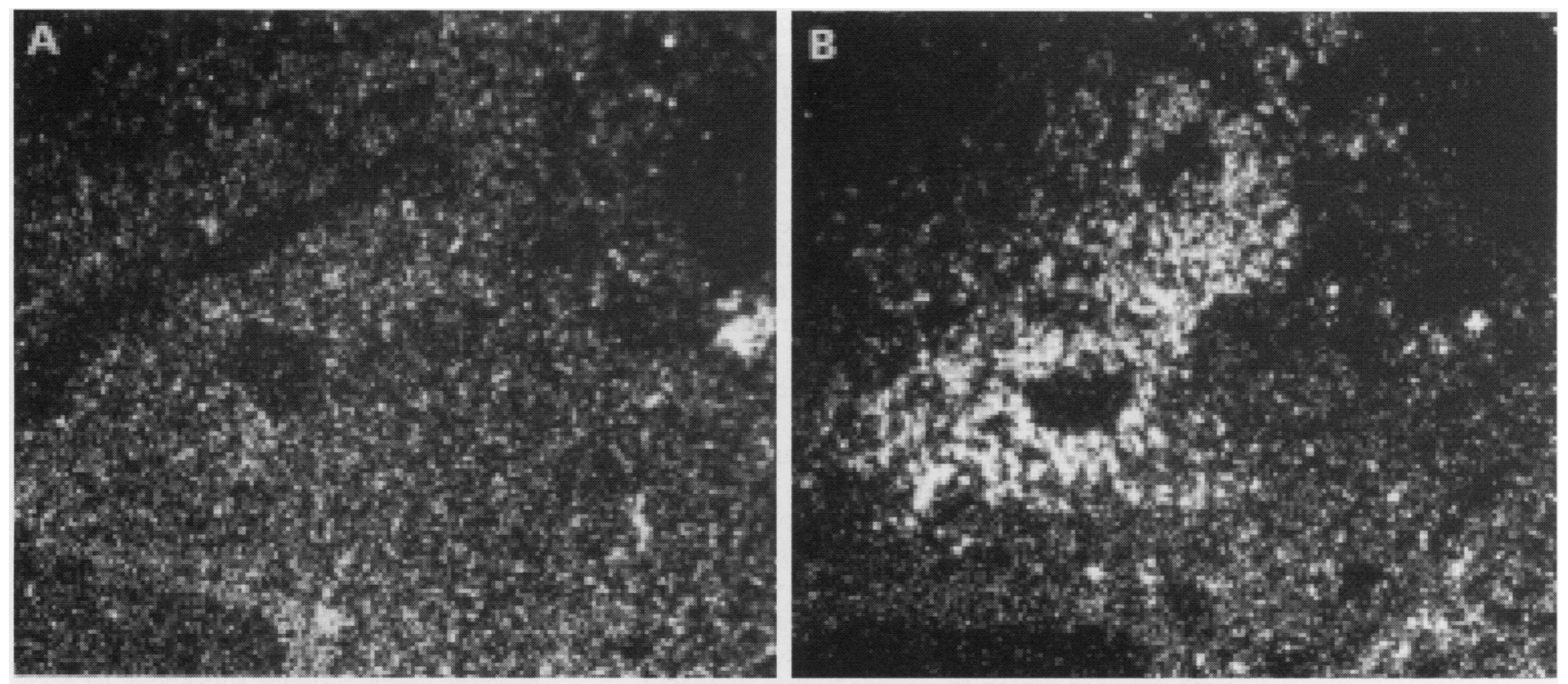

Figure 6 Darkfield examination of a tissue section taken from an animal 21 days after bleomycin treatment; sense ( $A$ ) and antisense (B) probes for type III procollagen have been applied.

cellular procollagen gene expression is upregulated to be addressed, but we are aware of no reports using these techniques to examine procollagen III gene expression in fibrotic disorders. In this study we used Northern analysis to measure changes in mRNA concentrations and in situ hybridisation to assess the distribution of cells containing the mRNA for procollagen III during the course of bleomycin induced pulmonary fibrosis. The results of Northern analysis suggested an increased concentration of mRNA for type III procollagen after 10 days, and whether expressed as a total amount, or as a ratio to $\beta$ actin, this increase was also apparent after 35 days.

We expressed type III procollagen mRNA concentrations in three ways (table). All methods have limitations, but many workers have used so called "housekeeping" genesfor example, $\beta$-actin-as standards for comparision. However, the use of such genes as suitable controls has been questioned as their products may themselves increase in the course of bleomycin induced fibrosis. ${ }^{18} \mathrm{We}$ found an increase in $\beta$-actin gene expression at 10 days (data not shown), but by 35 days, when gene expression for type III procollagen was enhanced, it had returned to control values.

To visualise the location of the procollagen III $\mathrm{mRNA}$ we examined the sections exposed to riboprobes labelled with sulphur-35 $\left({ }^{35} \mathrm{~S}\right)$ complementary to the mRNA (antisense probes); we compared these with sections exposed to sense probes not expected to hybridise as they have sequences identical to the mRNA of interest. The use of such radiolabelled probes gave us good spatial resolution allowing visualisation of individual cells (fig 4). Such cellular resolution was unattainable with probes radiolabelled with phosphorus-32 (data not shown). One problem with ${ }^{35} \mathrm{~S}$-probes is non-specific binding to lung tissue. Such binding is probably due to charge interactions and contamination with free nucleotides, which, although minimised by chromatographic separation, are impossible to remove completely. Non-specific binding is also minimised by adjusting the stringency of washes after hybridisation and exposure times of autoradiography. For this probe, however, the protocol gave the minimum background without loss of RNA-RNA hybrids and allowed visualisation of mRNA associated with individual cells. For each probe the protocol will vary and should be adjusted to give optimum results.

High background will mask cells of lower activity. In both control and bleomycin treated lungs more cells are likely to be active than we have shown here as there is a threshold under which activated cells cannot be detected. For example, it has been estimated that a gene copy number of at least 20 would be necessary to detect mRNA with a technique similar to that we have used. ${ }^{19}$

Our study shows the advantage of combining quantitative estimates of mRNA using solid phase hybridisation techniques and morphological assessment by in situ hybridisation. The dot-blot analysis suggests increased amount of mRNA but without the in situ hybridisation it would be impossible to delineate whether the increase was associated with activation of individual cells. Figure 4A shows that individual cells are activated and locates these cells in specific areas of the lung.

In normal animals gene expression was detected in cells present in subpleural areas (fig 5), indicating that many of these cells are actively producing procollagens. In other parenchymal areas of the lung no signals were detectable (fig 5). Given that cells are active in collagen synthesis even in the normal lung, ${ }^{8}$ this suggests that synthesis is probably below the threshold of detection of current in situ hybridisation methods. In bleomycin treated animals clearly enhanced concentrations of mRNA were associated with individual cells, suggesting activation of either transcriptional events in these cells or 
increased mRNA stability-that is, decreased degradation of mRNA. Cells with raised gene expression were most apparent in peribronchial and subpleural areas, mostly in the interstitium. This type of distribution has been noted previously and may reflect the mode of administration. ${ }^{13}$ Activated cells are probably fibroblasts (or myofibroblasts), although their precise identity needs to be established with cell specific immunohistochemical stains.

In situ hybridisation techniques such as these have recently been applied to fibrotic lung in humans for both type $\mathrm{I}^{20}$ and type III collagens. ${ }^{21}$ Similar findings to ours were described with increased expression of collagen genes in fibroblast-like cells. In this model, as with the human studies of Broekelmann et $a l^{20}$ the tissue areas in which cells seemed to be activated did not coincide with areas in which there was highly distorted architecture and fibrosis. Neither was there any obvious association between their activation and the presence of inflammatory leucocytes. This observation was somewhat surprising, because current hypotheses for the pathogenesis of pulmonary fibrosis usually involve mediators released by leucocytes and their subsequent activation of surrounding fibroblasts. For example, mediators such as transforming growth factor $\beta$ and insulin-like growth factor 1 released by isolated pulmonary macrophages are recognised to activate procollagen gene expression. ${ }^{1}$ However, other pathways are possible. Mediators may come from blood or blood elements-that is, platelets-or mechanisms independent of such mediators may be involved. For example, collagen synthesis may be enhanced directly by bleomycin, ${ }^{22}$ by breakdown products of type I procollagen, ${ }^{23} 24$ by altered mechanical forces, ${ }^{25}$ or by hypoxia. ${ }^{26}$ Clones of cells that are particularly rapid collagen producers may also proliferate, as has been suggested in human pulmonary fibrosis. ${ }^{27}$ The clusters of cells seen in our study would be consistent with such a hypothesis.

In summary, we have used two techniques to investigate the activation of the type III procollagen gene during the development of pulmonary fibrosis induced by intratracheal instillation of bleomycin. Using Northern analysis to measure type III procollagen mRNA we found a twofold to threefold increase compared with control animals. Furthermore, in situ hybridisation showed that this increase was at least partly due to activation of individual interstitial cells within the lung parenchyma.

We thank the Scleroderma Foundation in the United States and the Wellcome Trust in the United Kingdom for their support. We also thank Dr Paul Barton for valuable advice on in situ hybridisation techniques.

1 Mays PK, Laurent GJ. The regulation of collagen and elastin gene expression in normal lung and during pulmonary disease. In: Barnes PJ, Stockley RA, eds. Molecular biology of lung disease. London: Blackwell Scientific (in press).

2 Seyer JM, Hutcheson ET, Kang AH. Collagen polymorphism in idiopathic chronic pulmonary fibrosis. $\mathcal{f}$ Clin Invest 1976;57:251-7.
3 Kirk JME, Costa PE, Turner Warwick M, Littleton RJ, Laurent GJ. Biochemical evidence for an increased and progressive deposition of collagen in lung of patients with pulmonary fibrosis. Clin Sci 1986;70:39-45.

4 Kirk JME, Heard BE, Kerr I, Turner Warwick M, Laurent GJ. Quantification of types I and III collagen in biopsy lung samples from patients with cryptogenic fibrosing alveolitis. Collagen and Related Research Clinical and Experimental 1984;4:169-82.

5 Madri JA, Furthmayr $\mathrm{H}$. Collagen polymorphism in the lung. An immunohistochemical study of pulmonary fibrosis. Hum Pathol 1980;11:355-65.

6 Hay J, Shahzeidi S, Laurent GJ. Mechanisms of bleomycin-induced lung damage. Arch Toxicol 1991;65: 81-94.

7 Shahzeidi S, Sarnstrand B, Jeffery PK, McAnulty RJ, Laurent GJ. Oral N-acetylcysteine reduced bleomycininduced collagen deposition in the lungs of mice. Eur Respir f 1991;4:845-52.

8 Laurent GJ, McAnulty RJ. Protein metabolism during bleomycin-induced pulmonary fibrosis in rabbits. In vivo evidence for collagen accumulation because of increased synthesis and decreased degradation of newly synthesised collagen. Am Rev Respir Dis 1983;128:82-8.

9 Clark JG, Overton JE, Marino BA, Vitto J, Starcher BC. Collagen biosynthesis in bleomycin-induced pulmonary fibrosis in hamster. $f$ Lab Clin Med 1980;96:943-53.

10 Kelly J, Chrin L, Shull S, Rowe DW, Cutroneo KR. Bleomycin selectively elevates mRNA levels for procollagen and fibronectin following acute lung injury. Biochem Biophys Res Commun 1985;131:836-43.

11 Hoyt DG, Lazo JS. Alteration in pulmonary mRNA encoding procollagens, fibronectin and transforming growth factor- $\beta$ precede bleomycin-induced pulmonary fibrosis in mice. $\mathcal{f}$ Pharmacol Exp Ther 1988;246:765-71.

12 Raghow R, Lurie S, Seyer JM, Kang AH. Profiles of steady state levels of messanger RNAs coding for type I procollagen, elastin, and fibronectin in hamster lungs undergoing bleomycin-induced interstitial pulmonary fibrosis. F Clin Invest 1985;76:1733-9.

13 Laurent GJ, McAnulty RJ, Corrin B, Cockerill P. Biochemical and histological changes in pulmonary fibrosis induced in rabbits with intratracheal bleomycin. Eur $\mathcal{F}$ Clin Invest 1981;11:441-8.

14 Wilkinson DG, Bailes JA, Champion JE, McMahon AP. A molecular analysis of mouse development from eight to ten days post coitum detects changes only in embryonic globin expression. Development 1987;99:493-500.

15 Maniatis T, Fritsch EF, Sambrook, J. Molecular cloning. A laboratory manual. 2nd ed. New York: Cold Spring Harbor Laboratory, 1989.

16 Liau G, Yamada Yl, de Crombrugghe B. Coordinate regulation of the levels of type III and type I collagen mRNA in most but not all mouse fibroblasts. $\mathcal{F}$ Biol Chem 1985;260:531-6.

17 Chandler DB, Hyde DM, Cairi SN. Morphometric estimates of infiltrative cellular changes during the development of bleomycin-induced pulmonary fibrosis in hamsters. Am f Pathol 1983;112:170-7.

18 Phan SH, Kunkel SL. Lung cytokine production in bleomycin-induced pulmonary fibrosis. Exp Lung Res 1992;18:29-43.

19 Angerer LM, Cox KH, Angerer RC. Demonstration of tissue-specific gene expression by in situ hybridization Methods Enzymol 1987;152:649-61.

20 Broekelmann TS, Limper AH, Colby TV, McDonald JA Transforming growth factor $\beta_{1}$ is present at sites of extracellular matrix gene expression in human pulmonary fibrosis. Proc Natl Acad Sci USA 1991;88:6642-6.

21 Shahzeidi S, du Bois RM, Sheppard MN, Laurent GJ. Type III collagen gene expression in patients with idiopathic pulmonary fibrosis (IPF). Am Rev Respir Dis pathic pulmonary

22 Sterling KM, Harris MJ, Mitchell JJ, Cutroneo KR. Bleomycin treatment of chick fibroblasts causes an increase of polysomal type I procollagen mRNAs. $\mathcal{f}$ Bio Chem 1986;258:14438-44.

23 Katayama K, Seyer JM, Raghow R, Kang AH. Regulation of extracellular matrix production by chemically synthesised subfragments of type I collagen carboxypropeptide. Biochemistry 1991;30:7097-104.

24 Pacini A, Gardi C, Corradeschi F, Viti A, Belli C, Calzon $\mathrm{P}$, et al. In vivo stimulation of lung collagen synthesis by collagen derived peptides. Res Commun Chem Pathol Pharmacol 1990;68:89-101.

25 Sumpio BE, Banes AJ, Link WG, Johnson, G. Enhanced collagen production by smooth muscle cells during repetitive mechanical stretching. Arch Surg 1988;123: repetitive

26 Chvapil M, Hurych J. Control of collagen biosynthesis International Review of Connective Tissue Research 1968; 4:166-77.

27 Jordana M, Schulman J, Mcsharry C, Irving LB, Newhouse MT, Jordana G, et al. Heterogeneous proliferative characteristics of human adult lung fibroblast lines and clonally derived fibroblasts from control and fibrotic tissue. Am Rev Respir Dis 1988;137:579-84. 